\title{
ONE OR TWO VIEWS OF JUDAISM \\ PAUL IN ACTS 28 AND ROMANS 11 ON JEWISH UNBELIEF
}

Kenneth Litwak

\begin{abstract}
Summary
Many scholars since Vielhauer have viewed the Lukan Paul as standing in contradiction to the epistolary Paul. This essay contends that a proper assessment of the genre, audience, and function of Romans 11 and Acts 28:16-31 enables readers to see that both Pauls agree on several points regarding Jewish response to the gospel. Where there are differences, these are complementary. Both Pauls see a mixed response among Jews, the developing of a faithful remnant, and in both texts 'provoking to jealousy' is a critical element.
\end{abstract}

\section{Introduction}

Ever since Vielhauer's essay, 'The Paulinism of Acts', in which he sought to contrast the views of Paul's letters to those of Paul in Acts, it has been common in Lukan and Pauline studies to contrast these two 'Pauls'. ${ }^{1}$ One can readily find reference to two separate 'Pauline theologies', or 'two Pauls'. In order to determine how closely the Paul of Acts and the Paul of the Letters correspond to or complement each other, it is necessary to examine what each Paul has to say on specific topics. When doing so, it is essential to ask several questions. Is the statement by one of the Pauls exhaustive or complete - is there enough said by Paul on a given topic to say that we know what Paul thinks in Acts or his letters on a given subject? How do the contexts differ? Is one evangelistic, addressed to Jews, while the other is expository and addressed primarily to Gentiles? What is the function of Paul's

1 P. Vielhauer, 'On the 'Paulinism' of Acts', in Studies in Luke-Acts, ed. L. E. Kechand, J. L. Martyn (London: SPCK, 1968): 33-50. 
statements in given contexts? - since a statement by Paul on some topic, such as christology, must be evaluated in light of its function before we can simply create two parallel columns and claim that 'these two texts have different theologies'. ${ }^{2}$ We also need to ask when a difference is incompatible with - or complementary to, but not the same as - what Paul has said elsewhere. I contend that insufficient attention has been paid to these questions in comparing the Lukan Paul to the letter-writing Paul. Certainly, Vielhauer has been critiqued for failing to ask them. The views of Vielhauer and his critics need not be rehearsed here. ${ }^{3}$ In this essay, I am going to examine Luke's presentation of Paul's statements regarding Jewish unbelief in Acts 28:16-31 and Paul's own epistolary discussion of the same subject in Romans 11. While it is doubtless true that at the very least, Luke has shaped and summarised what Paul said (Luke himself says that Paul spoke all day long), and many believe that Paul's speech is a purely Lukan invention, that issue is not relevant to my purpose. This study will seek to answer the question: Are the admittedly Lukan Paul and the letter-writing Paul compatible in what each says regarding Israel in these two passages? Both Acts 28:16-31 and Romans 11 are pivotal sections within their respective books. Both deal with the same topic explicitly. I will demonstrate that, given an appropriate appreciation of the context of each text, Paul's views on Jewish unbelief are complementary in these two texts and the Paul of Acts and the Paul of the Letters do not contradict each other on this subject at these two

2 Contra e.g. Daniel R. Schwartz, ('The End of the Line: Paul in the Canonical Book of Acts', in Paul and the Legacy of Paul, ed. William S. Babcock [Dallas: Southern Methodist University, 1990]: 10) who asserts that Paul in Acts, contrary to Romans 911, does not speak of Israel's continuing primacy before God and God's future return to Israel. Schwartz therefore sees a contradiction between the two Pauls regarding the status and destiny of Israel. This fails, however, to ask about the differences in function, genre, and audience of Paul in Acts and Romans 9-11 completely, or why the fact that a topic is only treated in one of the two texts equals a contradiction.

3 See e.g. Steve Walton, Leadership and Lifestyle: The Portrait of Paul in the Miletus Speech and 1 Thessalonians (SNTSMS 108; Cambridge: Cambridge University, 2000): 3-12. David Wenham, in the first volume of the Tyndale House Acts Project ('Acts and the Pauline Corpus II: The Evidence of Parallels', in The Book of Acts in Its Ancient Literary Setting (AIFCS I; Bruce Winter and Andrew Clarke, eds.; Grand Rapids: Eerdmans, 1993): 215-58) considers several of the places that Acts and Paul's letters potentially intersect as well as places where one might expect them to intersect. While Wenham discusses Paul's journey to Rome and his imprisonment, Wenham does not specifically treat Acts 28 and neither does Vielhauer. My study contributes to this discussion in part by focusing on this section, which has not received sufficient attention in the debate over the two Pauls. 
points. I am not going to address directly the larger question of Luke's or Paul's view of Israel in general, ${ }^{4}$ but only the views expressed by the two Pauls towards ethnic Israel in these passages.

The results of my investigation hinge, in some measure, upon the definition of 'complementary' and 'compatible', and therefore I will begin by offering my understanding of these ideas. If one idea is 'complementary' to one or more other ideas, it expresses a concept that does not contradict the latter, when properly understood; and it could be seen as pointing towards the same or a similar trajectory as the latter. There is a fundamental difference in this regard between ' $\mathrm{A}$ and $B$ ' versus ' $A$ and $\sim A$ '. $A$ and $B$ might both be true, and while they point to different ideas, both ideas can be integrated into a larger schema or framework. A and $\sim \mathrm{A}$ cannot be integrated because they are mutually exclusive. This does not require that $\mathrm{A}$ be identical verbally to B. Paul in Acts could conceivably say one thing about Israel that is not present in Romans 11, and Romans 11 could include something that is absent from anything Paul says in the whole of Acts. That does not mean that there is a contradiction between these two passages per se. It is necessary to ask whether these two items point to the same or a similar trajectory, or whether they appear to exclude each other. Of great importance in this connection is interpretation. If Paul's words in Romans 11 are taken one way, they might exclude what the Paul of Acts says, while if they are interpreted another way, the two Pauls might speak in compatible ways. This will become apparent as we proceed.

\section{Acts 28:16-31}

At the end of Acts, Luke portrays Paul as a missionary, preaching to Jews who have not heard the gospel message. While the purpose of the text may be didactic, the narrative context and content differ from the epistolary context of Romans 11. The major interpretations of Acts 28:16-31 are well-known. They see this text as representing a 'farewell to Judaism'; or a 'tragic end' to the mission to the Jews; or a 'mixed

4 David Ravens, Luke and the Restoration of Israel (JSNTSup 118; Sheffield: Academic, 1995): 211, argues that, while there are significant similarities between the views of Luke and Paul in Acts 28 and Romans 11, their overall view of Israel in its relation to the Gentiles is different. 
conclusion' that is one part triumph and one part tragedy; ${ }^{5}$ or an ending that is open because the mission to the Jews will still go on; or an ending that is positive because some Jews do accept Paul's message, as has been the case elsewhere. ${ }^{6}$ The arguments for these positions need not be summarised. Instead, I am going to offer my understanding of Paul's message and view of Israel.

\subsection{Paul's Messages to Israel in Acts 28}

In Acts 28:16-31, Luke narrates two meetings between Paul and some leading Jews in Rome. The first meeting is described in Acts 28:17-22. Paul begins by addressing his listeners as 'men, brothers'. Paul then denies that he has done anything against the people or the customs of the fathers. Paul, through these words, places himself squarely within the people of Israel represented by his audience. Paul then says he was handed over as a prisoner from Jerusalem (28:17). The Romans examined Paul and determined that he had not done anything that deserved death (28:18), but when the 'Jews' spoke against Paul, he felt compelled to appeal to Caesar. Paul insists, however, that he had nothing with which to accuse 'my people' (28:19). Rather, it is because of the 'hope of Israel' that Paul is in chains (28:20), which refers most probably not to Jesus' resurrection but to 'the realization of the promises that God has made to his people, that is, the promise of Messianic salvation'?

These statements by Paul suggest at least two things. First, he identified himself explicitly with the people of Israel multiple times. Second, Paul believed, even after all the opposition he had faced in his preaching of the good news, that Israel's hope was still available and that this is the hope of which Paul had spoken in the past (cf. Rom. 11:26-29). Paul sees himself here as an Israelite: at one with the people of Israel and in sympathy with them and the customs of the fathers. The leading Jews do not disavow Paul, but say that they have heard negative things about the Way, and wish to hear more about it from Paul. In light of what is said at this first meeting, I find Beverly Roberts

5 Ben Witherington III, The Acts of the Apostles (Grand Rapids: Eerdmans, 1998): 804.

6 One can see this variety easily by looking through Luke-Acts and the Jewish People: Eight Critical Perspectives ed. J. B. Tyson (Minneapolis: Augsburg, 1980).

7 C. K. Barrett, A Critical and Exegetical Commentary on the Acts of the Apostles, 2 vols, (ICC; Edinburgh: T. \& T. Clark, 1994-98): 1240. 
Gaventa's assertion that the issue is not 'Paul's posture towards his own people', puzzling to say the least: ${ }^{8}$ Paul's posture towards his own people is precisely the point. He has not objected to the customs of the fathers, and he has neither spoken nor done anything against his people. He is only in the current situation because the Jews, who are set over against 'the people', spoke against Paul's release.

The subsequent meeting between Paul and the group to whom he had spoken on the previous occasion (assuming that $\pi \lambda$ Eíoves refers to the same group as in 28:17-23), was Paul's opportunity to proclaim the kingdom of God to his audience. The result of Paul's preaching, according to $28: 24$, was that some were persuaded, while others doubted. Acts 28:24 shows a mixed response on this specific occasion, and like similar events in Acts 13:46 and 18:6, does not convey a finality to Paul's Jewish mission. Paul's words in Acts 13:46, for example, do not represent 'a decisive and radical turning-point in Paul's mission'.9 Paul has already evangelised Gentiles in Antioch (Acts 11:25-26); as with other 'decisive' turning points, such as Acts 18:5 and 28:28, the same sentiments are expressed. The Jews are never abandoned, but the rejection of the gospel by some of them 'provided the occasion', though not the cause, for the mission to the Gentiles. ${ }^{10}$ Acts 28:24 and 28:30 frame the citation from Isaiah 6 and indicate that some, including Jews, continue to respond positively to Paul's preaching. ${ }^{11}$ This account should not be read as a final, decisive rejection for Jews as a whole, as that is contrary to the pattern already established in Acts and the first half of Acts 28:24.

Frequently, scholars commenting on this passage state that some accepted Paul's message, but overall the message was rejected, and the emphasis falls upon this 'but'. Tyson exemplifies this approach, arguing that although some are persuaded, the Old Testament citation places the weight of the passage on those who rejected Paul's preaching. Since the quotation from Isaiah and Paul's application of it appear to present the Jewish people as obdurate and unrepentant, there would seem to be an inconsistency in the text. Tyson resolves this inconsistency by arguing that while individual Jews do believe, the

8 See Beverly Roberts Gaventa, The Acts of the Apostles (Nashville: Abingdon, 2003): 365 .

9 Barrett, Acts: 657.

10 Barrett, Acts: 657.

11 Witherington, Acts: 803. 
people as a whole do not. ${ }^{12}$ This interpretation is problematic. The text says that 'some began to be persuaded but others began to doubt' (Acts 28:24). ${ }^{13}$ According to Luke's narrative there is a mixed response, and Luke offers no reason to reject this. Paul would not need to address the Jews who were persuaded with a prophetic critique. Paul only uses such a text in an effort to change the minds of those who doubted. Luke focuses more on the negative reaction of some Jews in the latter part of Acts, but this does not demonstrate that the majority of Jews, in Luke's view, rejected the message about Jesus. ${ }^{14}$ In Acts 14:4, 17:32 and 28:24, the divided response among Jews is seen in the use of oi $\mu \varepsilon ́ v . .$. oi $\delta$ é (cf. Acts 27:44). Paul's preaching does have some success, and we are not told that the group that did not believe is larger than the group that did, nor should such a view be read into the text.

Next Paul quotes from Isaiah 6. Paul begins by stating that the Holy Spirit spoke well through Isaiah to 'your fathers'. In Paul's first address to these Jews at Rome he spoke of the 'the fathers', and did not distance himself from them. This suggests that when Paul refers to 'your fathers', he is speaking of Israelites in the past who rejected God's message: neither all past Israelites nor even the fathers of all the Israelites present.

The obduracy to which Paul points has been a factor throughout Israel's history. This is evident in Israel's wilderness wanderings, such as the people's rejection of Moses' instruction regarding the rules for collecting manna and the response to the report of the spies sent to the promised land (cf. Deut. 10:16). The book of Judges shows a repeated

12 Joseph B. Tyson, 'The Jews and Judaism in Luke-Acts: Reading as a Godfearer', NTS 41 (1995): 36.

13 Contra I. Howard Marshall, The Acts of the Apostles (TNTC 5; Grand Rapids: Eerdmans, 1980): 424; Ernst Haenchen, The Acts of the Apostles, (Philadelphia: Westminster, 1971): 723; and others; '́твí⿴囗ovto should be understood as denoting believing the gospel. This is an alternate way for Luke to describe conversion or accepting the gospel message. Luke says nothing to lead a reader to think that this is not real 'faith', nor does he use this terminology in a similar context to mean anything else (cf. Acts 18:4; 19:8).

14 Robert L. Brawley (Centering on God. Method and Message in Luke-Acts [Louisville, KY: Westminster/John Knox, 1990]: 101) sees this as a plot device. He argues that "just as the demise of Judas has been neglected as the principal counterpart to the reconstitution of the twelve at the beginning of Acts, so the story of Paul and believing Jews has been neglected as the principal counterpart to unbelieving Jews at the end of Acts.' Paul and believing Jews align with the twelve tribes judged by the reconstituted twelve apostles, as unbelieving Jews are identified with hardened Israel in Isa. 6:9-10. Unbelieving Jews 'fall in with Judas'. 
cycle: Israel rejects God's ways; Israel is oppressed by its enemies; Israel calls out to Yahweh; and God delivers his people. 2 Kings 17:14 states that the reason that Israel was taken captive by Assyria is because they stiffened their necks, just as their fathers did (cf. Neh. 9:29; Isa. 48:4; Jer. 7:26; 17:23; 19:16). ${ }^{15}$

Paul, in Acts 28:25, declares that the message of Isaiah to the fathers of his audience applies to those present who do not believe his message ${ }^{16}$ because they were rejecting God's message as surely as Israel had been doing since the Exodus. Isaiah prophesied judgement upon the majority of Israel, but salvation for a remnant, after punishment and purification of Israel. This citation at the end of Acts implies that Israel is simply continuing in the way it always has, but also implies, through the unstated co-text in Isaiah 6, that a believing remnant will be saved.

\subsection{Paul's Remnant Theology in Acts 28}

Isaiah 40:5, echoed in Acts 28:28, points to this remnant idea. Both Isaiah 6:9-13 and Isaiah 40:5 point to the ingathering of a remnant. Isaiah 40:5 relates to the salvation of a remnant of Israel plus the nations. All flesh will see the salvation of God. God will bring salvation to both Israel and the nations (cf. Isa. 49:6). Isaiah 40:5 in Acts 28:28 speaks of salvation for a remnant of Israel plus the nations. Paul in Romans 11 will also speak about a remnant, which corresponds to the expectation in Isaiah 40 that God will return to Zion, ending the punishment of his people and gather a people from both Israel and the nations. Isaiah 40:1-5, Acts 28:25-28 and Romans 11:1-5, 12-16 all indicate that a remnant of both Jews and Gentiles will be gathered, built upon 'the Jew first' and after that 'Gentiles'.

The notion of a future, faithful remnant is pervasive in the Scriptures of Israel. Isaiah 10:20 refers to the actions of the remnant of Israel and those of Jacob who have been saved or delivered (oi

15 See the section entitled 'The Language of Prophetic Critique' in Mary C. Callaway, 'A Hammer that Breaks Rock in Pieces: Prophetic Critique in the Hebrew Bible', in Anti-Semitism and Early Christianity: Issues of Polemic and Faith, ed. Craig A. Evans and Donald Hagner (Minneapolis: Fortress, 1993): 22-29, for a discussion of the type and content of the prophetic critique in the Scriptures of Israel.

16 Darryl W. Palmer, 'Mission to Jews and Gentiles in the Last Episode of Acts', RTR 52 (1993): 65, asserts that 'the quotation is only implicitly applied to the present audience.' Furthermore, 'it is only the adverb "well” ( $\kappa \alpha \lambda \omega \varsigma)$, which links the quotation with the present audience.' 


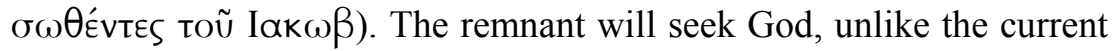
majority in Judah. In a prophecy of God's future reign over all the earth, Isaiah predicts that God will stretch out his hand and bring a remnant of his people from all the nations (Isa. 11:11; cf. Isa. 11:16). The list of nations in Acts 2 represents a remnant of Jews being gathered from far-off nations back into God's saved people. Jeremiah 6 begins with a warning to Judah to change its ways and seek God. Otherwise, the remnant of God's people will be gleaned like a vine (Jer. 6:9). Jeremiah 6:10 then asks, 'To whom will I speak and beg earnestly and he will listen? Behold their ears are uncircumcised and they are not able to hear. Behold the word of the Lord has become an insult to them. They are not at all willing to listen to it.' This is the same theme as Isaiah 6:9-10. The people cannot hear with their ears, for their ears have become dull. In both Isaiah 6:13 and Jeremiah 6:9, there is a remnant which shall remain after judgement; and the implication seems clear in Paul's citation of Isaiah 6:9-10 that once again, a future remnant of Israel will hear God's message with ears that can hear; while the nation itself, with ears which cannot hear, will reject that message, be judged and rejected from the remnant (cf. Jer. 27:20; Zeph. 2:9; 3:13; Zech. 8:12; 9:7). The use of Isaiah 40:5 by Simeon in Luke 2:30 regarding Jesus' future ministry, and by Luke of John's ministry in Luke 3:6, both point to the separation in Israel between a believing remnant and the rest of Israel, which is obdurate. Paul's use of Isaiah 40:5 in Acts 28:28 points in the same direction. ${ }^{17}$

With Isaiah 6:9-10 in Acts 28:26-27, and Isaiah 40:5 in Acts 28:28, Paul holds out the two realities for Israel, which have been present throughout its history. First, there is judgement upon those who reject Yahweh (cf. Rom. 11:7-10 for the same assertion). Then, there is a promise of salvation for a purified remnant. Jews who accept Paul's message and believe in Jesus, plus Gentiles who do likewise, will be part of the people who see the salvation of God. ${ }^{18}$

17 For a fuller analysis of the use of the Scriptures of Israel in Acts 28:16-31 and the remnant theme, see Kenneth D. Litwak, Echoes of Scripture in Luke-Acts: Telling the Story of God's People Intertextually (London: T. \& T. Clark, 2005): 184-97.

18 While Krister Stendahl (Final Account: Paul's Letter to the Romans (Minneapolis, MN: Fortress, 1995): 35) asserts that Rom 11:5 is the only place that 'the famous idea of the remnant' is used, this surely underestimates its presence in other texts, as seen in Acts 28, for example. This theme is clearly present in the use of the theme of the Isaianic New Exodus in both Mark and Luke-Acts. See David W. Pao, Acts and the Isaianic New Exodus (Tübingen: Mohr Siebeck, 2000); and Rikki E. Watts, Isaiah's New Exodus in Mark (Grand Rapids: Baker Books, 2000). 


\subsection{The Interpretation of Acts 28:28}

It has been argued by some that Acts 28:28 implies that Paul will no longer preach to Jews at all. This would stand in contrast to Paul's desire, expressed in Romans 11, to continue to win Jews to an acceptance of Jesus. Yet Paul's wording as given by Luke need not be construed in this fashion. The oppositional understanding of 28:28, which contrasts Jewish unbelief with Gentile belief, is based in part on taking kaí in an adversative sense, and taking ớkoúoovtå to mean that the Gentiles will be receptive. Salvation under this view is transferred from recalcitrant, stubborn Jews to Gentiles who will favourably receive the preaching of the gospel. This view also requires ignoring the evidence of similar episodes in Acts.

There are difficulties with this understanding of the text. First, Luke does not contrast the Jewish and Gentile responses, but announces that the gospel will go also to the Gentiles, who may potentially accept it. Kaí need not be taken as adversative but is more likely to be adverbial. Luke's use of kaí as an adverb with additive ('also') or ascensive ('even') force elsewhere follows a quite consistent pattern. ${ }^{19}$ According to Weatherly, Luke 'consistently inserts adverbial kaí into a clause immediately before the word or phrase expressing a new point added to the previous clause'. ${ }^{20}$ In Luke 2:4, for example, adverbial kaí

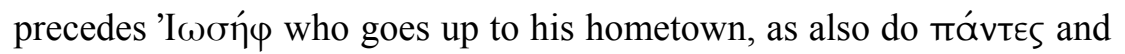

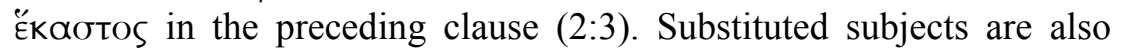
introduced with adverbial kaí in Luke 9:60-61; 11:17-18; Acts 1:2;

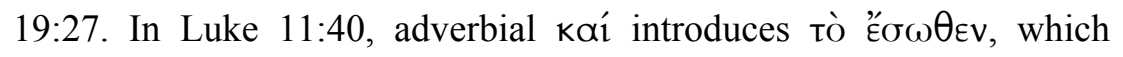
corresponds to ' $₹ \xi \omega \theta \varepsilon v$ in the preceding participial phrase (cf. Luke 14:7-12; Acts 19:21). Adverbial kaí also precedes verbs when their subjects or objects are the same as those in the preceding clause (cf. Acts $1: 3,10-11 ; 3: 24 ; 7: 44-45 ; 12: 3-4 ; 13: 32 ; 22: 28 ; 26: 9-10)$. From such texts Weatherly argues that 'the new element which is added to the idea of the previous clause - the word or phrase emphasized by adverbial kaí - is the one that follows kaí, not the one that precedes it. ${ }^{21}$ In every other instance in Luke-Acts the emphasis falls on the

19 See Jon A. Weatherly, Jewish Responsibility for the Death of Jesus in Luke-Acts (JSNTSup 106; Sheffield: Sheffield Academic, 1994): 142-45, for examples and further discussion of Lukan usage of adverbial kaí.

20 Weatherly, Jewish Responsibility: 142.

21 Weatherly (Jewish Responsibility: 144) argues that this extends to Luke adding adverbial kaí to his sources where it is lacking (cf. Luke 6:36; 11:34; 17:26; 17:37). 
word following adverbial kaí where, as in Acts 28:28, kaí is preceded by a pronoun (cf. Acts $1: 3,11 ; 7: 45 ; 10: 39$ ). Therefore, if Luke's consistent pattern in using adverbial kaí carries through to Acts 28:28, the emphasis falls on the following verb, not the preceding pronoun. ${ }^{22}$ So kaí by itself does not support a contrast between unreceptive Jews and receptive Gentiles. Rather, it suggests that the Gentiles, like the Jews, will hear Paul preach.

The verb ákoú $\omega$ occurs 89 times in Acts, and 65 times in Luke's Gospel. While there is often a contrast made by scholars between the Jews in Acts 28:25-28 and the Gentiles in 28:28 in that the latter, so it is thought, will 'hear' in the sense of positively responding to Paul's message, Luke's use of the verb ákoú $\omega$, both in this passage and elsewhere in Acts, hardly requires such a reading. In Acts 28:26, Paul quotes Isaiah to say that the people of Israel will hear but not understand. Israel physically heard Isaiah's words, as Paul's audience physically heard his words, but that does not mean that Paul's Jewish audience will respond positively. Neither does Paul's use of ákoú $\omega$ in Acts 28:28 imply that the Gentiles will do anything more than physically hear, even if Acts does show that Gentiles often respond positively (but cf. the response of Gentiles in Acts 14:2-5 at Iconium, 14:19 at Lystra, and 17:16-34 at Athens).

Similar uses of ókoú $\omega$ for physical hearing are seen throughout Acts. In Acts 1:4, Jesus speaks of the promise of the Father, which 'you have heard from me'. Nothing indicates that this is more than an acoustic phenomenon. In Acts 2:1-11, Luke speaks three times of the crowd hearing (physically) the disciples' speaking in tongues. Peter points to this 'hearing' in Acts 2:33, referring to what the crowd sees and hears. Acts 4:4 reports that many who heard Peter's speech believed, but nothing in the text suggests that this act of hearing is anything but physical. In Acts 9:7, Saul's companions 'hear' a voice but see no one. This hearing certainly cannot be linked to faith. Without examining every occurrence of ákoú $\omega$ in Acts, it is fair to say that Luke generally uses this word in its normal, physical sense. Hearing in Acts does not imply responding in faith. It is only a necessary precondition, as Paul himself asserts in Roman 10:14, asking how Israel can believe if it has not heard. Numerous examples exist in

22 Haenchen (Acts: 724) errs in applying to aútoì kaí a rule for relative pronouns. Even if, as Haenchen argues, the kaí should not be translated, it still has syntactical force. 
Luke-Acts where the sense of '̊koúw is neutral or negative (cf. Luke $12: 3 ; 16: 2$ - used in a negative way; Acts 17:32 - used in an unreceptive sense by Gentiles; 24:24.) There is, therefore, no need to understand ókoúoovtå in 28:28 in anything but a neutral sense. Luke presents Paul as saying that now that he has preached to the Jews of Rome first, and some do not believe, he will turn to the Gentiles as well, in order that 'they will hear also'. It is unjustified to read into ókoú $\omega$ in Acts 28:28 more than the idea that the Gentiles, now that the Jews have heard the good news first, will hear it second. It is helpful to note in this connection Paul's use of the word 'first' in Acts 13:46. He spoke first to the Jews; and now, when some of them have rejected his words, he will turn to the Gentiles.

Lastly, the prior evidence from Acts is crucial. Acts 13:46-47 shows that in Pisidian Antioch, Paul met with a similar mixed response from Jews, and this led him to begin preaching directly to Gentiles. Yet in Acts 14:1, Paul is once again in a synagogue preaching to Jews. Luke reports that a large number of both Jews and Greeks believed. By the logic applied by some scholars to Acts 28:28, this makes no sense because Paul's very similar words in 28:28 are construed as a close to Paul's mission to Jews. In Acts 18:4, Paul is in the synagogue in Corinth, trying to persuade Jews and Greeks. Then, in Acts 18:6, Paul makes a seemingly closing statement to his mission to the Jews and says he will go to the Gentiles. Yet, this is not Paul's final act of preaching to Jews. In Acts 19:8, Paul is again back in a synagogue, this one in Ephesus, preaching to Jews. Clearly, then, Paul's language as presented in Acts prior to 28:28 means nothing more than that in this specific city, Paul will shift his focus from the Jews, and preach directly to Gentiles. Based on these accounts, the most reasonable reading of the data is that Luke is building a pattern and sees Paul's ministry as continuing to be to both Jews and Gentiles. Hence, Acts 28:28 suggests the same thing that we will see in Romans 11, where Paul shows that he continues to seek the salvation of both Jews and Gentiles.

\subsection{Acts 28:28 as Rhetoric}

Little consideration has been given to the rhetorical force of this verse within Paul's speech, other than suggestions that 28:28 offers justification for Paul's later preaching to the Gentiles, or similar ideas. I contend that this fails to do justice to the logic of Paul's speech. Paul 
preaches to the Jews, testifying concerning the kingdom of God and Jesus from the Scriptures of Israel. His Jewish audience has a mixed response to his message. Paul's reported words are aimed at those who doubt. Paul first confronts them with the message of Isaiah 6. Then, still addressing this same part of the audience, Paul says that the Jews should know that 'this salvation has been sent to the Gentiles and they will hear also'. Since we see nowhere in the text that Paul has told his audience that he should preach first to Jews, and his audience does not see him as having a responsibility to preach to Jews primarily or alone, there is no narrative logic for Paul to announce to doubting Jews that he is going to preach to the Gentiles. Why would they care? No indication is ever given in Acts that such a pronouncement from Paul led to any protests about the impropriety of preaching to Gentiles. Nor is there evidence that Paul's words can be understood to mean that salvation is being taken from the Jews and given to the Gentiles. Paul states that this salvation has been sent to the Gentiles in the past. This has already taken place. Since Paul is currently proclaiming and offering this salvation to his Jewish audience, and the same salvation has already been sent to the Gentiles, we must not understand Acts 28:28 to mean that the recipients of this salvation have changed. Luke's audience already knows, most probably, that there are Gentile Christians in Rome. Since no justification for preaching to Gentiles is needed, and no implication is presented of making salvation unavailable to the Jews, this statement must have another purpose.

I propose that Acts 28:28 serves in Paul's rhetoric to provoke his doubting Jewish audience to come to faith, as the Gentiles will. This is supported by the negative evidence given above. There is no statement about status change in 28:28. Paul is not announcing to his audience that they have lost anything, nor telling his audience an irrelevant fact. Nor does this statement seem to carry the sense of mocking; for example 'You were too foolish to accept my message, but the Gentiles have enough common sense to do so.' Instead, there is rhetorical (persuasive) value in Paul's statement. Paul seeks, through the prophetic critique in Acts 28:25-27, to provoke his audience to accept his message (not castigate them for unbelief). Acts 28:28 has a similar function. Paul announces to his audience that the salvation offered by God to them will also be offered to Gentiles, who will likewise have an opportunity to respond. If Gentiles have access to this salvation provided by Israel's God, should not members of Israel respond as 
well? This provides an explanation for Paul's statement within the context of this speech and a reasonable rhetorical function for it. Its purpose is to persuade his audience to accept his statements. Paul, then, as he describes in Romans 11 (see below), seeks with these words to provoke his Jewish listeners to jealousy of the salvation being offered to the Gentiles, but being refused by these doubting Jews, and thus to change their minds.

\section{Israel in Romans $11^{23}$}

Romans 11 is part of a letter that addresses theological matters explicitly, unlike Luke's narrative that, while no less theological, is less explicit about the author's theology. Paul is dealing with the specific issue of Israel's current rejection in large numbers of the gospel, and explicating what this means about God and his promises in Scripture. In Acts 28:16-31, Luke provides a narrative account of Paul's preaching to Jews who as yet know little of the Way except that it is spoken against everywhere (Acts 28:22); and Paul's concern as Luke presents it is to testify concerning the kingdom of God and to persuade his audience with regard to Jesus from the Scriptures. In contrast, Paul's purpose in Romans is to treat various aspects of the problem of Jewish unbelief in Jesus, so it should come as no surprise that the specifics of Paul's speech in Acts and his discussion of the issue in Romans 11 differ in many respects. The differing narrative and epistolary contexts make this almost inevitable. In Acts, Paul does not raise the question of why many Jews have not been persuaded concerning Jesus. ${ }^{24}$ Paul in Acts 28 does not seek to explain how this

23 I am assuming here the unity and coherence of Romans 11 within both Romans 911 and within the whole letter. See the convincing argument of E. Elizabeth Johnson, The Function of Apocalyptic and Wisdom Traditions in Romans 9-11 (SBLDS 109; Atlanta, GA: Scholars, 1989): 141-75; and William S. Campbell, 'Divergent Images of Paul and His Mission', in Reading Israel in Romans: Legitimacy and Plausibility of Divergent Interpretations, Cristina Grenholm and Daniel Patte, ed. (Harrisburg, PA: Trinity, 2000): 200-203.

24 Stendahl's assertion (Final Account, 36) that in Acts 'nothing really came of [Paul's preaching] - a couple of women' is to drastically underestimate what Acts records. While Acts reports that in most synagogues Paul eventually faced opposition (except, notably, at Berea), Luke does not say that none but a couple of Jewish women believed Paul's preaching. Luke reports a mixed response and if one is going to make recourse to Acts, one ought to take what Acts says seriously. For example, Acts 17:412 asserts twice that people present in the synagogue, who are distinguished from Godfearers and Greeks, believed. These must be Jews. Acts 18:8-10 similarly asserts that 
rejection can be correlated with Israel's position as God's covenant people, or say anything about a future, different response among ethnic Israelites to Jesus. In Romans 11, Paul is concerned with God's foreknowledge and election of Israel, while this is not an explicit topic of Acts 28:16-31. These differences, however, arise clearly from the different purposes and genres of the two texts. These differences, therefore, do not constitute a contradiction between the Lukan Paul and Paul the letter writer. They simply reflect topics that are appropriate to one context but not the other. That does not make the two Pauls at odds over the current state of Israel vis-a-vis Jesus.

Moreover, there are important points of contact between what Paul says of Israel in Romans and what Paul says in Acts 28. First, Paul in Acts 28:17-22 identified himself clearly as part of the people of ethnic Israel. The same can be seen in Romans 11:1. Cranfield notes the force of this statement within Paul's larger argument. Paul is asserting that he is proof that God has not rejected the Jews, for God would have 'hardly chosen a Jew as His special apostle to the Gentiles, had He cast off His people'. ${ }^{25}$ Paul identifies himself as a Jew in three ways: 1) he says he is an Israelite; 2) he is a descendant of Abraham; and 3) he is a Benjamite, which most likely means simply that Paul is a pure Israelite, not a proselyte nor a member of a tribe that is somehow special. ${ }^{26}$ Through this self-identification, Paul emphasises his identity with God's people and demonstrates God's ongoing faithfulness to his people. So both Acts 28:16-31 and Romans 11 begin with Paul's selfidentification as an Israelite, part of God's people.

Luke's presentation in Acts 28:16-31 shows a mixed response by Jews to Paul's preaching and the formation of a redeemed remnant of believing Jews. Likewise, in Romans 11, Paul speaks of a mixed response and a believing remnant. Paul says in Romans 11:1-5 that

Jews believed, including a likely intertextual echo of the very same story in 1 Kings about Elijah that Paul cites at the beginning of Romans 11 . There are many in the city who belong to God. Stendahl is so concerned to show that salvation for Israel is a separate, parallel track from that which God has provided for Gentiles that he seems compelled to play down evidence of Jewish conversion in Acts or Paul's letters. Jacob Jervell, ('The Church of Jews and Godfearers', in Luke-Acts and the Jewish People: Eight Critical Perspectives, vol. 2, Joseph B. Tyson, ed. (Minneapolis, MN: Augsburg, 1988), states that 'Luke's church consists primarily of Christian Jews, the heirs of Israel' (p. 11), which seems more judicious in handling the data of Acts.

25 C. E. B. Cranfield, The Epistle to the Romans (Edinburgh: T. \& T. Clark, 1979): 543.

26 James D. G. Dunn, Romans 9-16 (WBC 38b; Waco, TX: Word Books): 635. 
Israel has not been completely rejected, but that there is a believing remnant. J. Ross Kramer suggests that Paul's reference to Elijah probably includes an allusion to the 'still, small voice' episode and that this implies that the size of the remnant is much larger than Paul knows. ${ }^{27}$ This would emphasise even beyond Paul's words the reality of God's election and salvation of a remnant and warn us against assuming that in Paul's day, those who responded positively to the gospel were by far the minority within Israel. Cranfield understands the number 7000, based as it is upon seven, the number of completion or perfection, to point not to an actual number but to the reality that God is being faithful to his people in his election and that this is an open remnant, both in Elijah's day and in Paul's day. In both cases, the remnant exists and has a future as a matter of grace. ${ }^{28}$ This understanding of Paul's reference to Elijah likewise reinforces the reality of a remnant of Israel. The mixed response of Israel is emphasised again in 11:7, where Paul states that those who were chosen obtained (salvation), while those who were not chosen did not. So both Pauls agree that there is a mixed response, one part of which is a believing remnant, stated explicitly in Romans 11:5 and implied in Acts 28:25-28.

Objections have been raised to a reading of Romans 11:1 that points to a believing remnant. It is asserted by Gager that this is part of a domesticated portrait of Paul as an anti-Jewish Christian. ${ }^{29}$ Gager asserts that Paul in Romans is dealing with Gentiles only, who are arrogantly anti-Semitic. The audience of Paul's letter to the Romans was made up solely of Gentiles. ${ }^{30}$ Since this is a fundamental assumption for Gager in reading Romans, one must ask what the force of Romans 2:17-25 is. ${ }^{31}$ One also must wonder why Paul spends so

27 J. Ross Kramer, Heralds of the Good News: Isaiah and Paul in Context in the Letter to the Romans (Leiden: Brill, 2002): 235. Richard B. Hays has argued, compellingly that Paul most likely expects his audience to consider the larger co-texts of passages he cites. Hays states that 'the full force of the quotation is apparent only to a reader who recognizes its original narrative context. Paul is arguing from the story, not narrating it as something new to his audience', Conversion of the Imagination: Paul as Interpreter of Israel's Scriptures (Grand Rapids: Eerdmans, 2005): 8. Paul's regular use of the device of metalepsis makes Wagner's suggestion almost certain, thus strengthening a remnant understanding of Paul's view of Israel's status and destiny.

28 Cranfield, Romans: 547-48.

29 John G. Gager, Reinventing Paul (Oxford: Oxford University, 2000): 37-39.

30 Gager, Reinventing Paul: 51.

31 Gager (Reinventing Paul: 102) acknowledges this and similar texts in Romans explicitly but explains them as examples of rhetoric by an unreliable author. In Rom. 2:17-25, Paul, according to Gager, is engaging a fictive Jewish competitor for Gentile 
much time agonising over Israel, if he is trying to convict a Gentile audience of anti-Semitism. It leaves Romans 9-10 inexplicable, except as an overly-drawn out and complicated statement that Israel has not turned to Jesus as of yet, and this saddens Paul. It is always problematic to assert that an author could or would not have done something, but it is difficult to see Romans 9-10 fitting into a document intended solely for Gentiles. Like Stendahl, Gager rejects the clear evidence of Acts that Paul successfully preached to some Jews. Gager argues that the application of rhetoric to Paul's argument in Romans 11:1 shows that Paul is challenging his audience's misunderstanding of the situation. Paul plays the role of an 'unreliable author'. ${ }^{32}$ This makes Romans 11:1 a surprise to the implied readers (and modern interpreters!). Gager argues that the remnant refers to those Jews who 'proclaimed the Torah's message regarding the Gentiles'. ${ }^{33}$ The core problem with Gager's view is that his understanding of remnant utterly fails to account for the very scriptural texts cited by Paul in Romans 11 that point to a different understanding of the remnant concept. 1 Kings 19:18, cited in Romans 11:3-4 has nothing to do with Israelites speaking of God's plan for Gentiles. Rather, it shows that while the majority of Israel may have turned from faithfulness to God, there are many who are faithful.

Paul's combined citation of Deuteronomy 29:4 (which points to a lack of spiritual perception and should be read in the context of Deuteronomy 29:18) in Romans 11:6, and Isaiah 29:10 (which speaks of the inhabitants of Ariel, David's city, as being blind) in Romans 11:8, asserts that Israel has poor spiritual perception. Paul in Acts 28:25-27 asserts the same idea that Israel is spiritually unperceptive. While Paul does not explicitly cite Isaiah 6:9-10 in Romans 11, it is likely that this text, cited in Acts 28:25-27, is echoed here. ${ }^{34}$ This assertion is based upon the parallel language and idea of eyes that cannot see and ears that cannot hear, and a dull heart (a combination unique to Isa. 6:9-10 and Deut. 29:4); and on the presentation of the spiritual lack of perception as the result of divine judgement (seen in

converts; he does not address 'Jews' (116). This is a highly imaginative reconstruction, which Gager simply asserts without offering evidence for it.

32 Gager, Reinventing Paul: 74.

33 Gager, Reinventing Paul: 137.

34 Barrett, Acts: 1237. 
both Isa. 6:9-10 and 29:10). ${ }^{35}$ Both here and in Acts 28, Paul speaks of those within Israel who have not obtained salvation through Jesus as having eyes that cannot see and ears that cannot hear, even if the specific citation is different. In Romans 11, Paul is using Deuteronomy and Isaiah to point to the fact that what is happening now to Israel is 'no different than what happened more than once in the past. Israel now is showing no greater obtuseness than it did in the past'. ${ }^{36}$ The Paul of Acts makes the same point when he applies Isaiah 6:9-10 to 'your fathers'. Paul is saying that his audience is acting the same way that its ancestors acted in being blind to God's purposes and therefore rejecting God's purposes. ${ }^{37}$ The citation from Psalm 69:22-23 in Romans 11:9-10 speaks similarly of eyes that are darkened so that they cannot see. Again, this forms a close conceptual and verbal parallel with Acts 28:26-27. The Lukan Paul and the Paul of Romans 11 both understand part of their audience to have rejected the gospel because they have eyes that cannot see and ears that cannot hear. Even without an intertextual echo of Isaiah 6:9-10, the thought in Romans 11 is clearly parallel to Paul's statement in Acts 28:25-27.

Romans 11:11 begins a description by Paul of the effect of this spiritual blindness and deafness that has a significant parallel to Acts 28:28. The Paul of Romans says that the rejection of the gospel by some Jews has led to salvation for the Gentiles. This theme is developed in Romans 11:12-16. In both Romans 11 and Acts 28:28, the result of the refusal by some Jews to accept the gospel is that Paul has turned to the Gentiles to preach to them so that they might hear as well. In Romans 11:11, Paul says that it is because of Jewish rejection of the gospel that the way has been opened for Gentiles to be preached to and to be saved. Paul seeks to save some of his own people by making them jealous of the Christ-based salvation embraced by some Gentiles. ${ }^{38}$ In Acts 28:28, Paul asserts that, since part of his Jewish audience has rejected his message, he will now go to the Gentiles who

\footnotetext{
35 See Cranfield, Romans: 550; Dunn (Romans: 648) suggests possibly a 'sideways glance to Isa. 6:9-10'.

36 Dunn, Romans: 649.

37 See Litwak, Echoes of Scripture in Luke-Acts: 189-90.

38 The purpose of moving the Jews to jealousy on Paul's part is to move them to action, according to Joseph A. Fitzmyer, Romans: A New Translation with Introduction and Commentary (New York: Doubleday, 1993): 599, 611. This is the same thing that Paul in Acts 28:28 is doing by telling the Jews he is turning to the Gentiles.
} 
will have the opportunity to hear his message. This order of the Jews first, Gentiles second, is seen both in Romans 11:16-24, in which Israel is presented as the 'first' lump of dough, and the natural branches present on the tree first; and in Paul's normal custom in Acts of going to the synagogue in a new city and preaching first to the Jews and then, following his rejection by some Jews, as at Antioch (Acts 13:45-6) and Thessalonica (Acts 17:5), to preach to Gentiles second. On this pattern, both the Paul of Acts 28 and the Paul of Romans concur.

This sequence provides a further important correspondence between Acts 28:16-31 and Romans 11. In Romans 11:11 Paul states that salvation has come to Gentiles in order to provoke Israel to emulate ${ }^{39}$ the Gentiles in accepting the message of the gospel. ${ }^{40} \mathrm{He}$ does the same thing in Acts 28:28. In his rhetorical strategy, Paul says that the Gentiles will hear the good news in order to make Jews jealous. ${ }^{41}$ This provides an explanation for the presence of this statement within Paul's speech. In Romans 11:14, Paul asserts that the reason that he magnifies his ministry and preaches to Gentiles is in the hope of provoking his own people to jealousy, even while affirming that he is an apostle of Gentiles. Romans 11:14b states that the reason for this is for the purpose of some Jews being saved. As I have argued above, this seems to me the purpose of Acts 28:28, because Luke is not there merely

39 While the word may mean 'provoke to jealousy' in Rom. 10:19, here $\pi \alpha \rho \alpha \zeta \eta \lambda \tilde{\omega} \sigma \alpha 1$ means 'provoke to emulation'. See the discussion in Richard H. Bell, Provoked to Jealousy: The Origin and Purpose of the Jealousy Motif in Romans 9-11 (WUNT 63; Tübingen: J. C. B. Mohr, 1994): 40-41.

40 The contention of Mark D. Nanos (The Mystery of Romans: The Jewish Context of Paul's Letter [Minneapolis, MN: Fortress, 1996]: 249-50), that Paul does not expect Jews to be jealous of his success in converting Gentiles, but that he wants them to be jealous of his ministry because they (other Jews) are not doing what he is doing, and are therefore suffering from the 'eschatological curse' of being 'hardened', is intriguing but overly subtle. This seems to go well past the evidence available in Romans and ignores Rom. 11:14b, which connects provoking the Jews, Paul's own people, with the goal of saving some of them.

41 Bell (Provoked to Jealousy: 326-27): argues that in Acts, Luke shows the Jews as envious of Paul's success and zealous for a different understanding of the importance of the Torah, but that Luke does not show the Jews being provoked to jealousy as Paul speaks of in Romans 11. What Bell does not do, however, is look at Paul's specific statements about turning from the Jews and going to the Gentiles and asking what Paul meant. Bell only considers the Jewish reaction. Paul's statements, such as in Acts 13:42-47 and his act in 13:51 of shaking the dust off his feet, need to be explained in the context of Paul's speech and what he hoped to obtain by doing this. Paul's continuing mission to Jews throughout Acts can hardly mean that Paul is simply washing his hands (or feet!) of his own people. Rather, he is seeking to incite them to reconsider. 
presenting the petty Paul who, having his feelings hurt by rejection, is saying 'to perdition with you unbelieving Jews', which is the rhetorical force of the more typical interpretation of this verse. Whatever the reason for Paul's 'modest hope expressed here', ${ }^{42}$ he is clearly making the point that not all Israel would respond through his ministry..$^{43}$ The same thought is seen in the use of Deuteronomy 32:31 in Romans 10:19, in which Paul quotes Moses as saying that God will make Israel jealous by a nation that is not a nation. Paul is seen in Acts 28:28 carrying out this strategy of speaking to Gentiles to make Jews jealous. This correspondence is important because the motif of provoking to jealousy is critical to Romans 11. Other accounts in Acts show that it is reasonable to interpret Paul's rhetorical strategy in Acts 28:28 as telling his audience that he will go to the Gentiles, who will likewise hear, as an attempt to provoke his hearers to accept his message. In Acts 13:46 Paul, after some Jews believe but others reject his preaching, tells them that since they have refused to listen, he will turn to the Gentiles. While Luke records that the Gentiles are happy to hear this, we must ask why Paul would say this to his unbelieving Jewish audience. Again, I believe it is to provoke Jews to jealousy, so that they do not allow the Gentiles to receive salvation while they themselves squander the opportunity. Paul's statements in Romans 11:11, 14 offer a helpful commentary on Paul's approach in Acts 28. This is not to say that Acts 28:28 is explicable only through Romans 11:11, 14. Rather, since Paul is clearly speaking to Jews about Gentiles in order to get a different response from those who doubt, we are justified in seeing Romans 11:14 as giving Paul's rhetorical strategy a name, 'provoking to jealousy'.

What comes next is Paul's comparison of Jews and Gentiles to dough and olive trees in Romans 11:25-36, which is a theological discourse by Paul addressed to believers (regardless of their ethnic background), and which has no counterpart in Paul's preaching in Acts. Paul's statement in Romans 11 that a time is coming when all Israel will be saved also goes beyond what the Paul of Acts says. ${ }^{44}$ Yet again,

42 Dunn, Romans: 657.

43 Cranfield (Romans: 561) says that the conversion of individual Jews through Paul's ministry would be 'few in number'.

44 There are numerous theories about how to deal with Paul's statement that all Israel will be saved, because of its apparent conflict with the rest of Romans 9-11. I find most compelling the view of N. T. Wright ('The Letter to the Romans', in The New Interpreter's Bible, vol. 10 [12 vols; Nashville: Abingdon, 2002]: 689) that Rom. 
it must be kept in mind that Paul is depicted in Acts as preaching to Jews, some of whom do not embrace Jesus as Messiah, and not Jewish or Gentile believers. Paul's citation in Acts of Isaiah 6:9-10, however, and Luke's observation of a mixed response in Acts 28:24 are compatible with Paul's assertion in Romans 11:25b that a partial hardening of Israel has occurred. Paul's bold statement in Romans $11: 26$ as a prediction for the future does not stand in contrast to what is indicated in Paul's final speech in Acts or indeed in Acts in general. While it does point in a direction that might not be the trajectory for Israel implied in Acts, the interpretive difficulties of Romans 11:26 on its own should warn us against too readily perceiving a contrast. Cranfield notes four alternatives and while he argues that this refers to the entire ethnic nation of Israel but not necessarily every single individual, ${ }^{45}$ Wright's view that Paul refers to the 'whole family of Abraham, Jew and Gentile alike', and that this will happen during the course of time through these individuals coming to Christian faith, ${ }^{46}$ seems more satisfactory in being consistent with what Paul currently sees happening in the present moment: that a large part of Israel has rejected the good news of Jesus as Messiah, but God has still been faithful to his promises to Israel. One important point is that Paul's focus in Romans 11:26-29 on salvation for Israel based upon God's promises corresponds closely to Paul's statement in Acts 28:20 that he is in chains for the hope of Israel - God's fulfilment of his promises to Israel of messianic salvation (see above on Acts 28:20). Another point of contact between Romans 11:25-29 and Acts 28:16-31 is the assertion on Paul's part that in Romans 11:25 that Israel has been hardened. This is part of God's plan (cf. Rom. 11:7-10). Paul's citation in Acts 28:25-28 speaks to the same thing, for when Paul quotes Isaiah 6:9-10, he asserts through Isaiah's words that 'the unbelief of Israel is no unhappy accident but part of God's intention'. ${ }^{47}$

11:26a refers not to all of ethnic Israel but to all of the elect, including Jews and Gentiles. This agrees with how I understand the 'Israel of God' in Gal. 6:16, and the nature of the elect in Galatians in general.

45 Cranfield, Romans: 576-77.

46 N. T. Wright, 'Romans', in The New Interpreter's Bible, vol 10 (Nashville: Abingdon, 2002): 689.

47 Barrett, Acts: 1245. 


\section{Conclusion}

I have argued that Acts 28:16-31 and Romans 11 share significant conceptual and verbal features in common: Paul's self-identification as an Israelite; a mixed response to Paul's preaching by Jews evidencing a believing remnant of Jews and an obdurate group of Jews; and Paul's strategy of announcing plans to preach to Gentiles in order to provoke his Jewish listeners to jealousy. I have also noted that the genre and audience differences between Acts 28:16-31 (Jews hearing of Jesus for the first time) and Romans 11 (Christians to whom Paul is explaining Israel's rejection of Jesus) enable us to see the additional emphases of Romans 11 on the impropriety of Gentile boasting and the promise of eschatological salvation for all of Israel as complementary, not contradictory. Therefore, the understanding of the relation of Israel to the preaching concerning Jesus in Acts 28:16-31 and Romans 11 agree on important issues and do not contradict in any respect. Rather, the letter-writing Paul and the Lukan Paul appear to be compatible on the matter of the status and destiny of Israel in these two passages in so far as the emphases of each can be compared. While other texts in Acts could be compared to Romans 11, the similarity to other encounters between Paul and Jews in Acts suggests a consistent agreement in viewpoint between the Paul of Acts and the Paul of the Letters on Jewish reception of the gospel. Perhaps on this point, then, we can suggest that there is only one Paul, not two. This analysis further suggests that the question of the correspondence/contrast between the Paul of Acts and Paul of the letters be revisited with due consideration given to genre, audience, and function of the respective texts. 